\title{
Mediating Effect of Job Embeddednesss on the Relationship between Quality of Work Life and Organizational Commitment in Taraba State Higher Institutions of Learning. A Conceptual Paper
}

\author{
Musa Leah, Garba Bala Bello, Aliyu Mukhtardaneji, Aminu K. Kurfi
}

\begin{abstract}
Today, the issue in organizational commitment can be clearly seen in abseentism of staff, non challant attitude towards work, making other personal business a priority allowing ones primary obligation to suffer. It is quite obvious in academic environment, in an attempt to meet up with family and social needs, most academic staff have side businesses that compete with their research and teaching responsibilities in the school. This has become necessary because the government has failed in its duties to higher institutions, which are constraint that made many academics work under difficult circumstances. This study assesses the mediating effect of job embeddedness on the relationship between work life balance and organizational commitment. Literatures were reviewed related to the variables in the research with consistent findings. This study selected different combination of variables peculiar to Nigerian environment pioneered by previous authors, the selected determinants of quality of work life revealed positive relationship with job embeddedness and organizational commitment. Hence, it is concluded based on the literature reviewed that quality of work life has significant relationship with job embeddedness and organizational commitment. It is therefore advised that employers should encourage employees in the higher institution of learning to be embedded in the organization, because highly embedded employees are needed to achieve improved future organizational commitment.

Index Terms - Organizational Commitment, Quality of work life, Job embeddedness.
\end{abstract}

\section{INTRODUCTION}

In today's world, the role of human resource management has gone beyond just recruitment to ensuring environment for employees to contribute as long term assets to the organization [85]. [30]proposed that the overall stability of the organization is maintained in terms of productivity, financial viability and employee commitment, in other to sustain that organization should also focus on retaining skilled individuals not only in recruitment. Employees are likely to stay in an organization because of different reasons, some stay because they are emotionally attached to the

Musa Leah Department of Business Administration Federal University, Wukari

Garba Bala Bello, Department of Business Administration and Entrepreneurship Bayero University Kano

Aliyu, Muktar Daneji Department of Business Administration and Entrepreneurship Bayero University Kano

Aminu, K. Kurfi Department of Business Administration and Entrepreneurship Bayero University Kano. organization, and others are obliged to stay while others stay for share sense of responsibility [20]; [86]. [57] attest that employees who are committed to their organizations are less likely to leave. The concept of organizational commitment has been the focus of managers and human resource department in many organizations because it reduces employee turnover and increases productivity and retention [40]. [87], suggest that human resource department can seize the opportunity to understand the factors that create employee commitment and use the knowledge to leverage organization. Today, the issue in organizational commitment can be seen in absenteeism of staff, non-challant attitude towards work, declining in employee productivity, increase in turnover rate and having other personal business that is a priority allowing ones primary obligation to suffer, it is quite noticeable in academic environment, instead of observing lecture free weeks, schools get busy few weeks to examinations, trying to cover up the lost times. Organizational commitment has been an essential factor in determining the success of an organization, when there is a constant decrease in productivity then there is a problem in commitment. Organizational commitment is the main factor in maintaining and increasing productivity, it also reduces turnover rate, therefore, decrease in productivity and increase in turnover rate signal problem of organizational commitment [82], [47]. Lack of organizational commitment gives negative effect on employee productivity, turnover rate which to large extent contribute immensely to the failure of organization [16]; [18]; [14]; [12]; [41]. Research concluded that organizational commitment has significant impact on employee productivity and employee turnover rate [35]; [47]; [8]: [48]; [57].

Low productivity has been linked to organizations and institutions in Nigeria and has over the years tagged with poor reputation, and that tarnishes the image of organizations [1]. Relatively, in many emerging economies, labor productivity outputs appear higher to Nigeria's 3.5 USD/hour as stated by National Bureau of Statistics [103]. In another record by World Bank Nigeria was ranked among the worst in productivity, out of the 174 countries Nigeria is ranked 167 based on how countries lose in economic productivity [102]. Higher institution is one of the strong holds of education, because they train other levels, their commitment to work cannot be over emphasized. Without a good education system, a country is in danger, for instance, in the world higher institution's ranking, only 19 universities made it to the top 


\section{Mediating Effect of Job Embeddednesss on the Relationship between Quality of Work Life and Organizational Commitment in Taraba State Higher Institutions of Learning. A Conceptual Paper}

200 universities in Africa, which means only 12\%, of Nigerian universities made it to the first 200 Uni ranking, [104]. Apart from the low ranking, Nigeria is also rated low in research productivity (publications), citations of publication; international outlook that comprises award winning of Nobel prize and field medals, and international collaboration. All these are an indication of low organizational commitment.

Quality of work-life (QWL) is the total quality of an employee's work-life at an organization, when the quality of work life is stable it helps in increase productivity so also reduces turnover rate [60]; [25]; [30]. The concern in quality of work life is not only to improve life at work but also life outside work; it is nothing rather than having a work environment where an employee's accomplishments become more important. QWL is not a unitary concept, but a multidimensional construct that has incorporated a variety of interrelated factors, researchers explained that what constitutes quality of work life depends on the environment and the industry where the study is conducted [51]. It is suggested that organizations offering better QWL are likely to gain leverage in productivity and retaining valuable people [30]. An organization that does not measure and improve QWL may face increasing turnover, declining productivity and limited ability to attract and retain qualified replacements [72]; [30].This is a complex problem, however, because it is difficult to isolate and identify the attributes which affect the quality of working life in all employees, because to balance between an employee's work demands and outside interests or pressures entails a thorough search to understand what employees actually need, knowing well that what appeals to one might not be applicable to other [77].

Job embeddedness is the idea that individuals may become immersed in their surroundings or circumstances to the extent that it is hard to separate themselves from those situations [63]. Job embeddedness concept is focusing narrowly to explain why people stay in their jobs, it also indicates decisions to participate broadly and directly in an organization and it focuses beyond dissatisfaction related leaving [54]. Job embeddedness refers to a broad set of influences on an employee's decision to stay on the job, and reduces the chance of employees quitting their jobs [26]; [63] These influences include on-the job factors such as bonds with colleagues and the fit between one's skills and what the job demands. In addition, it includes off-the-job factors. Some examples of off-the-job factors are personal and community commitments [63]. Based on Empirical studies it was discovered that people that are embedded in their jobs are less likely to quit than those who are not embedded. Employees who feel strongly embedded and committed may define their relationships with their employers as long-term relationships, as opposed to employees who have lower levels of embeddedness and commitment to their organisations [59]; [63]. Therefore the aim of this research work is to investigate whether job embeddedness mediates the relationship between work-life balance and organizational commitment.

\section{PROBLEM STATEMENT}

The inability to identify what constitute the quality of work life to employees of higher institutions create the problems of low productivity, abseentism, turnover and intention to leave to keep increasing in various higher institutions which it is an indication of lack of organizational commitment. Organizational commitment among staff is very important as employees that are committed would remain attached to the organization and give in their best. Human resources are considered the main factor that makes up an organization without them nothing in the organization would get done. One of the major problems organization face is the loss of them, when they leave the organization, the knowledge, expertise and experiences over the years is gone. It is quite unfortunate now; that the turnover rate and intention to leave an organization is increasing by the day, in an economic news release of bureau of labour statistics the annual turnover rate in higher institution from 2015 to 2019 kept increasing thus, $31.25 \%, 31.4 \%, 32.6 \%, 34.0 \%$; and any rate above $20 \%$ is considered high rate of turnover. Knowing that most employees turnover intentions and actions are greatly affected by lack of commitment to the organization [66]; [7] $\&$ [31]. To be more successful in an organization and for managers to achieve the desired commitment needed from the employee's quality of work life must be improved, this means that employees must be comfortable to perform to expectations [21]. In a study to conceptualized quality of work life by Kwahar, and Iyortsuun, [51], explained that environment where the research is being conducted determine what constitutes quality of work. Therefore, it is important to understand what constitute quality of work life in higher institutions.

Higher institutions play a vital role in nation's socioeconomic development through their primary functions of teaching, learning, research and consultancy [70]; hence, the quality and ability of staff to perform is key because they are the most significant factor in the education process. Their area of work is not only to produce scientific knowledge but also to train individuals [70]; [42]. For this to be successful higher institutions need to be equipped, to aid academicians in performing their duties and responsibilities, and even be willing to do more than their terms of reference and be committed to their organization [28]; [42]. Furthermore, higher institutions in Nigeria experience various degrees of low rating apart from the low ranking in universities, in measuring the productivity of a country in education by world human capital index in 2020, Nigeria ranked 167 out of 174 countries with a value of $0.36 \%$. Nigeria's Labor Productivity dropped by $1.14 \%$ in 2018 as reported by the Computer and Enterprise Investigations Conference [105]. Different degree of decline in research publication between $30 \%$ to $70 \%$ based on analysis of number of publications for 10years [44]. While in citation count analysis, the most cited higher institution had only 7.25 cite per article, far below what is obtainable in other countries, and the international outlook impact factor the highest collaboration share in Nigeria is $0.67 \%$.

Looking closely at the population of previous studies, it ranges between 100 to 250 respondents from one faculty or one institution in which it cannot allow for generalization and the method used in analyzing data are mostly correlation, regression and factor analysis is not been carried [11]; [80]; 
[84]; [27]; [64]. This study will look at all the higher institutions in Taraba State and use Structural Equation Modeling where there is explicit assessment of measurement error, estimation of latent (unobserved) variable via observed variable and model testing where structure can be imposed and assessed as to fit of the data.

Recent studies on QWL and organizational commitment confirm that there is a positive relationship between QWL and organizational commitment [6]; [10]; [46]; [78]; [89]; [93]; [98]; [13]; [17]; [79]; [74]; [84]; [96]. While aiming to address the Job Embededdness phenomenon among employees, in reducing unwanted turnover, abseentism, improving productivity and achieving sustainability in organizational commitment, some studies emphasizes the need to explore the link between job embeddedness with human resource practices (QWL) and organizational commitment [43];[ 61]. Having understood that QWL have an influence on commitment, with the call for meadiating variable to further explain the why the relationship exist and to further strengthen the relationship, this study will consider the mediating effect of employee embeddedness in the relationship between quality of work life and organizational commitment.

\section{LITERATUREREVIEW}

\section{Conceptual Review}

\section{A. Organizational Commitment}

The meaning of organizational commitment was first provided in 1956 by Whyte. He explains it thus: "a man of organization not only works for the organization, but he also commits himself to the organization, and feels as if he belongs to it". Many researchers have studied organizational commitment after Whyte and this has made it an important subject in the area of organizational studies. Steers, [88] and Mowday, [65] further explained that organizational commitment will increase productivity, while unwanted behaviors such as late coming, abseentism, intention to quit and quitting will be minimized. [3], developed an early model that has received considerable attention on the concept of organizational commitment, based on their observation that existing definitions of commitment at that time reflected emotional attachment towards an organization, the recognition of costs associated with leaving an organization and a moral obligation to remain with an organization. [58], defined organizational commitment as the desire to be a member of an organization and not to complain about their organization, and also described organizational commitment as the psychological likings and devotion that employees have to their organization. Other researchers argue that organizational commitment could be considered a bond or link between an employee and organization, as both employees and organizations benefit from employees' organizational commitment [107], additionally, [83] define organizational commitment as the feeling of responsibility that an employee has towards the mission of the organization.

Therefore, [53] added that Organizational commitment is a psychological state that keeps employee to the organization; and also a bond to the entire organization. [11], further added that organizational commitment is a strong belief in organizational objectives and principles by an employee, and readiness to put forth a substantial effort on behalf of the organization and a resilient aspiration to remain as a member of the organization. The level of commitment employees feel towards their organization is determined by how engrossed they are in pursuing organizational goals and objectives [80]. Organizational commitment as defined by Yousef [100] view organizational commitment as an employees' psychology towards his attachment to the organization, because it plays a vital role in determining if an employee will stay in the organization for a longer period of time and work passionately towards achieving the goals of the organization. [23], added that organizational commitment is the employee's willingness to identify with the goals and values of the organization in which he or she works for.

\section{B. Quality of Work Life}

Quality of human resources hinge on the quality of work life obtainable through the organization, the concern in quality of work life is not only to improve life at work but also life outside work; it is nothing rather than having a work environment where an employee's accomplishments become more important. This means policies and procedures that make employees work more interesting should be implemented, these policies include autonomy, recognition, job security and career satisfaction, homework balance, safe and healthy environment, development and external rewards. [80]. [51] conducted a research on describing the essential dimensions of quality of work life by performing a principal components analysis on the identified indicators of quality of work life in the Nigerian industries, with the understanding that what constitute quality of work life depends on economic and socio-cultural factors existing in that locality. In the study five underlying construct of quality of work life was discovered as 'remuneration and benefits', 'job security and career satisfaction', 'training and opportunities for personal autonomy', 'home-work balance' and 'safe and healthy environment'.

\section{i. Remuneration and Benefits}

Remuneration and benefits are very important aspect in organization's activities, which unravels other relationships; every organization has different system it operates, both financial and non-financial benefits affects employees commitment. Furthermore, employees have different preferences; consequently the strategy to follow in satisfying employees is complicated [52]. Therefore, organizations need to develop reward system that suits their employees. One of the most important roles of human resource management is to guarantee that organization finds a customized reward system to retain talented employees that can be the driving force of the organization in order to compete in the global market [76]; [45]; [49].

In studies conducted by [99], [22] and [62], they revealed that remuneration and benefits influence employees and they ranked top of employee preference because they enable them fulfill their basic needs of life which leads to so many accomplishment. [36] observed that remuneration has 


\section{Mediating Effect of Job Embeddednesss on the Relationship between Quality of Work Life and Organizational Commitment in Taraba State Higher Institutions of Learning. A Conceptual Paper}

positive effect on employee performance and if properly managed will result in higher organizational performance, while comprehensive model of remuneration builds employee commitment, assures fulfillment and creates prospects for development and success of the organization while multiplying its positive effects [92].

\section{ii. Job Security and Career Satisfaction}

Keeping employees committed and fulfilled require more than just remuneration and benefits, respect, trust, security and healthy environment. Career path honest communication and transparency are needed, because most organization strives for job security and career satisfaction, but not all achieve this target. It is therefore important for an organization to know more about factors that can increase career satisfaction and how it fits into overall success of the organization, Society for Human Resource Management, [106]. There is no doubt that employees are the most valuable resources in the organization, thereby, keeping workers satisfied in their career and assuring their security strengthen organization and can be seen in lower turnover, higher productivity, increased profits loyalty that leads to organizational commitment. Career satisfaction is significant issue to continue for a long time, employees are eagerly looking for, as well as job security [91].In contrast, an organization that cannot guarantee job security will find that its employees swiftly pursue more stable employment with less risk, causing that organization to suffer from high turnover rate which will negatively affect it. When an organization loses its customers trust because of high turnover, it will inevitably lose business and revenue. [64]. Job security denotes the span of time employees can anticipate continuing in their job. In general, employees prefer a job that they can occupy for the long term, which works to the benefit of the organization.

\section{iii. Training and Opportunities for Personal Autonomy}

Training is a planned determination intended at increasing employee abilities for doing a particular job and increasing person's knowledge for vocational purpose. It is also a process that aims at bringing individuals up to a preferred standard for current and would-be assignment. Training alters behavior and knowledge, changes employee approach to work to increase organizational achievement and perform to an acceptable standard [9]; [32]; [33]; [34] \&[ 90]. To become committed to the organization, training is vital. It helps employees to practice their current skills to a better standard, thus improving general attitude towards the organization and enhance employee's confidence. Employees perform better on the job when adequate knowledge and information about their roles are at their fingertips, and that is possible through training [94]. Training also lessens nonproductive work time as well as increase value by reducing employee error and the resulting wastage.

It is not enough to train, but opportunity for autonomy is important to freely put into practice the skills and knowledge acquire. Autonomy in work place depends on organization, for some organizations it means employees are allowed to set their own schedule which means employees can decide how their work should be done, no matter which idea is being used.
Autonomy increases career satisfaction, studies showed that employees with autonomy not only have career satisfaction but greater productivity. Autonomy increases motivation and happiness along with decreasing turnover. [81]. Autonomy is one of the important roles in building true employee commitment to the organization, it also allows employee to design his work in ways that allows him perform better, gives employee opportunity to learn every day even through mistakes, build loyalty and trust and chance to practice theories learnt.

\section{iv. Home Work Balance}

Work-life balance is the capacity to ensure there is no overlapping that can create conflict between work, family and social activities [19]. The entire time invested in work or personal life do not matter when priorities are set right, striking the right balance between leisure and work is not easy but achievable [56]. Therefore, it is necessary to state that, work life balance is affected when personalities are in disagreement. In ensuring organizational commitment, managerial strategies need to be put in place in managing work-life balance; when it is achieved; employee and organization benefit [108]. Being comfortable with both work and family cannot be over emphasized, therefore, finding the right balance between work and personal life are important for both employees and employers to stay ahead of competitors. Work-life balance is critical to employee's commitment in any organization; hence it has turn out to be a subject of great significance in today's business world. These concepts are clearly interrelated and affect a majority of employees in their lives. Employee commitment is influenced by workplace as well as personal life, because today's employees encounter daily challenges [67]. Thus, it is obvious that employees with enhanced work-life balance contribute more towards the attainments of organizational goals.

v. Safe and Healthy Environment

Various hazards are present in today's work environments, and it's the employer's duty to keep their employees safe from these hazards. Health and safety in work place are vital to the well-being of employees and employer. Safe healthy environment is important because it prevents illness and injury, reduces health and safety, avoid serious consequences. Not having safe and healthy environment can have negative impact on the organization; however, much of this can be avoided if organization realizes the need for having a health and safety program and implements it, [97]. [50], asserts that organizations are lawfully liable for creating and sustaining a working environment where employees are able to perform their duties safely with no fear of risk to their health and welfare. Work place arrangements that allow for effective consultation on environmental health safety matters are required. Human resource manager is expected to be a model in the workplace to educate, communicate and monitor employee to maintain safe and healthy environment. In order to have employees that are committed to their organizations, employers need to identify hazards, detect problems and take protective action as well as prevent the reoccurrence of any stated case. A healthy work environment is about being safe, where employees feel protected and enjoy the physical work 
environment. When employees have the feeling of safety in an environment, they dedicate themselves and concentrate on their duties knowing that the environment is safe to work so that it can give employees the room to be committed to their organization and compete favorably in the dynamic business environment.

\section{Employee Job Embeddedness}

Job embeddedness is the extent of an employee's involvement within a social system. It results from various forces like links, fit, and sacrifice in the organization and the community, it can be seen as powers that stimulate employee retention, it is like a web that attaches people to organization [63]. Fit is the extent to which an individual's ability is compatible with the organization and surrounding environment. Links refer to the number of connections that a person has in the workplace. Sacrifice is defined as what people would have to give up (i.e. perceived cost of material or psychological benefits) if they decide to leave their organization. Employees with an advanced level of bonding cultivate more sense of obligation in the web and leaving the organization becomes difficult [39].

Job embeddedness is a gathering of social, psychological, financial and environmental powers that involve employees into an emotional ground [4]; [48]. Job embeddedness is distinctive because it emphases on both work and non-work forces [54] that root employees to become involved in their current job [15]; [24]; [95]. [63], affirm that employees who have many links recognize good fits and expect substantial personal sacrifices related with leaving are likely to be embedded in their organizations. Job embeddedness is regularly seen as a web of forces that cause employees to be held in their jobs [55]; [63]. When employee's abilities, career ambitions and personal values match job requirement, development opportunities afforded by the organization employees become embedded in their jobs [54]; [69].

\section{EMPIRICAL REVIEW}

[6], carried out a study on the influence of quality of work life and organizational commitment among academics in Malaysian public university with the aim to ascertain the relationship between quality of work life on organizational commitment. A sample size of 153 was obtained using G Power analysis and the result indicated a positive relationship between quality of work life and organizational commitment.

[10], conducted a study on quality of work life with organizational commitment in Turkey; the aim was to investigate the relationship between quality of work life and organizational commitment. A sample size of 224 was used using regression analysis and the result indicated a positive relationship between quality of work life and organizational commitment.

[46], conducted a study on the role of quality of work life in determining organizational commitment in Saudi Arabia, the aim was to determine the relationship between the quality of work life and organizational commitment. The data was collected from a random sample of 312 in the organization; descriptive statistics on the data support the significant relationship of quality of work life and organizational

\section{commitment.}

[78], carried out a study on influence of quality of work life and organizational commitment in Nigeria, the aim was find out the relationship between quality of work life and organizational commitment. A sample size of 300 employees was used across the organization and it was observed that employee commitment is largely influenced by quality of work life.

[89], conducted a study to investigate the relationship between quality of work life and organizational commitment in Indonesia with a sample size of 90 employees. Multiple regression analysis was used to analyze the data and the result indicated a positive relationship between quality of work life and organizational commitment.

[93], studied the influence quality of work life and organizational commitment in Indonesia with the aim to determine the relationship between work life balance and organizational commitment. 92 employees were used as sample size, the technique used in the analysis was a simple linear regression technique and the result showed a positive relationship between quality of work life and organizational commitment.

[98], conducted an analytical study of quality of work life and organizational commitment in India, the aim was to find out the relationship between quality of work life and organizational commitment. Data was analyzed using multiple regressions and the result showed a positive relationship between quality of work life and organizational commitment.

[13], carried out a study on the effects of work life balance and organizational commitment of accountants in Turkey with the aim to ascertain the relationship between work life balance and organizational commitment. It is a survey research with 498 respondents, data was analyze using SPSS and the result indicated a positive relationship between the constructs.

[17], conducted a study on influence of work life balance on commitment in Ghana, the objective of the study was to determine the relationship between work life balance and commitment. Descriptive cross- sectional survey design was used with the sample of 115 employees, Pearson correlation was used to analyze the data. The result showed a positive relationship between work life balance and organizational commitment.

[101], conducted a study on quality of working life with organizational commitment in Iran, and the aim was to determine the relationship between quality of work life and organizational commitment. Questionnaire was collected from 30 samples, and correlation was used to analyze the data. The result showed a positive relationship between quality of work life and organizational commitment.

A study was conducted by [27] on quality of work life and organizational commitment in Turkey. The aim was to determine the level of commitment of nurses in the hospital and the result showed that the quality of work life and commitment are at medium level while there is positive and significant relationship between quality of work life and organizational commitment.

[79], explore the quality of work life and organizational 


\section{Mediating Effect of Job Embeddednesss on the Relationship between Quality of Work Life and Organizational Commitment in Taraba State Higher Institutions of Learning. A Conceptual Paper}

commitment with the aim to determine if there is a relationship between quality of work life and organizational commitment with a response rate of 206. Descriptive statistics and correlation matrix was used to analyze the data and the result showed a positive relationship exists between quality of work life and organizational commitment.

[74], studied quality of work life and organizational commitment among academic in public institution of higher learning Malaysia, the aim was to investigate the relationship between quality of work life and organizational commitment. 250 sample was drawn out of the total population, and multiple regression was used to analyze the data. The result indicated positive relationship between quality of work life and organizational commitment.

[84], studied the impact of quality of work life on organizational commitment on academicians working in Turkey, the aim was to determine the relationship between quality of work life and organizational commitment. Multiple regression analysis was carried out to analyze the data and the result indicated a positive relationship between quality of work life and organizational commitment.

[96], conducted a research on work life balance on organizational commitment in India, the aim was to find out the relationship between work life balance and organizational commitment in the public and private sector. Pearson correlation method was used to analyze the data and the result showed a positive relationship.

[71] Investigated the relationship between quality of work life and organizational commitment of faculty members at Islamic Azad University Teran, Iran, under 127 faculty members with the sample size of 97 respondents selected through random stratified sampling. Spearman's correlation coefficients, multiple correlation method, LISREL, Friedman Test were used for data analysis. The T- statistic and Fisher statistic were applied to measure the demographic variables. Result showed that there is positive relation between the QWL and organizational commitment it means organization commitment is the result of high QWL.

[75], carried out a study on relationship between QWL and Organizational Commitment, stratified random sampling was used for data collection while Pearson correlation coefficient was used for analysis and kolmogorov-Smirnov test was used to identify the statistical population normality. The result showed direct and significant relationship between QWL and organizational commitment.

[73], studied the relationship between QWL and Organizational Commitment amongst employees in Malaysian firms. The aim was to investigate the relationship between QWL and Organizational Commitment and to ascertain the extent of QWL on employees. A quantitative approach research, was conducted using random sampling for data collection. Data were analysed from factor analysis with varimax rotation, mean, standard deviation, regression analysis used as statistical tools. Result of the research work showed that there is a positive relationship between QWL and organizational commitment. In conclusion, the literature review on quality of work life is clear that there is appositive relationship between quality of work life and organizational commitment.

\section{THEORETICAL FRAMEWORK}

A. Hygiene factor theory

Hygiene factor theory was propounded by [37], according to Herzberg, hygiene factors are what cause dissatisfaction among employees in the workplace. In order to remove dissatisfaction in a work environment, these hygiene factors must be eliminated. There are several ways that this can be done but some of the most important ways to decrease dissatisfaction would be to pay reasonable wages, ensure employees job security, status, salary, fringe benefits, work conditions, good pay, paid insurance, vacations and to create a positive culture in the workplace. [37], considered the following hygiene factors from highest to lowest in importance: company policy, supervision, employee's relationship with their boss, work conditions, salary, and relationships with peers. The results of Herzberg's theory can vary if the test is conducted in different industries. The differences are due to the intensity of the labour requirement and the duration of employment [68]. Herzberg gives an illustration that working in an unpleasant environment like an office that is too hot in the summer and too cold in the winter, can be miserable an employee cannot be committed in an unfavorable environment. In contrast, those factors that are intrinsic to the job, such as achievement, recognition, interesting work, increased responsibilities, advancement, and growth opportunities lead to satisfaction, increased productivity and commitment.

\section{CONCEPTUAL FRAMEWORK}

The two main variables are quality of work life and Organizational commitment, which are the independent and dependent variables respectively. The dimensions of the independent variable are remuneration and benefits, job security and career satisfaction, training and opportunities for personal autonomy, home-work balance, safe and healthy environment. The dependent variable dimensions are links, fit and sacrifice. The mediating variable used job embeddedness. The three key variables (the independent variable, the dependent variable and the mediator variable) and how they relate, gave rise to this research work.

Figure 1 below is the conceptual framework presenting the relationships between the independent, the mediator and the dependent variables of the study. It is representing how both independent and mediating variable influence the dependent variable. 


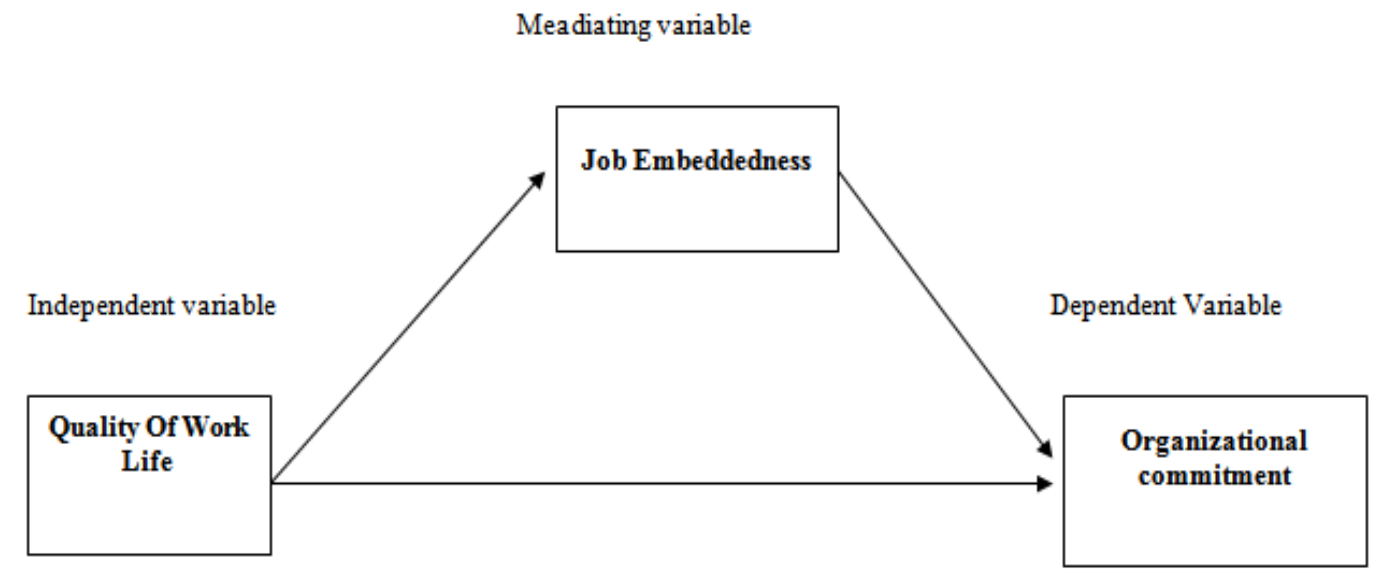

Figure 1: The Conceptual Framework

Source: Author (2021)

\section{PROPOSED RESEARCH QUESTIONS}

This study proposed to address the following questions:

i. To what extent does remuneration and benefit influence organizational commitment?

ii. To what extent does job security and career satisfaction influence organizational commitment?

iii. To what extent does training and opportunity influences organizational commitment?

iv. To what extent does home-work balance influences organizational commitment?

v. To what extent does safe and healthy environment influences organizational commitment?

vi. To what extent does remuneration influences job embeddedness?

vii. To what extent does job security and career satisfaction influence job embeddedeness?

viii. To what extent does training and opportunity for personal autonomy influences job embeddedness?

ix. To what extent does home work balance influences job embeddedness?

x. To what extent does safe and healthy environment influences job embeddedness?

xi. To what extent does job embeddedness mediate the relationship between quality of work life and organizational commitment?

\section{CONCLUSION AND RECOMMENDATIONS}

It is clear that organization cannot get desirable result without employees being committed to the organization, and employees are committed to the organization when the quality of work life is satisfying to them because quality of work life is an indicator to achievement. While job embeddedness secures the commitment, to achieve the goals of the organization employers are expected to provide enabling environment for employees to be embedded in the organization, which will help them function well. Therefore, based on the reviewed literature it was discovered that Job Embeddedness is a tool in reducing abseentism, turnover intentions, turnover rate, improving productivity and achieving sustainability in organizational commitment. To achieve improved future organizational commitment, highly imbedded employees are needed in the organization.

\section{REFERENCES}

[1]Abimbola, S. A., Dele, O. \&Owowumi, O. (2017).The Influence of Leadership Styles on Employees' Performance: A Study of Selected Private Universities in Ogun State, Nigeria. Global Journal of Commerce \& Management Perspective. 6(2) 5-13 ISSN: 2319-7285

[2]Alfred, P., Alexander, N., Huong Le, Z., \& Connie, Z. (2018). Organizational Commitment In The Context Of Multinational Corporations: A Critical Review And Directions For Future Research, International Journal Of Human Resource Management, DOI: 10.1080/09585192.2018.1511614 [3]Allen, N. J., \& Meyer, J. P. (1990). The measurement and antecedents of affective, continuance and normative commitment to the organisation. Journal of Occupational psychology,63(1)1-18

[4]Allen, D. G., Peltokorpi, V., \& Rubenstein, A. L. (2016). When "embedded" means "stuck": Moderating effects of job embeddedness in adverse work environments.Journal of Applied Psychology, 101(12), 1670-1686. https://doi.org/10.1037/apl0000134

[5]Allen, N.J. \& Meyer, J.P \& (1991). A three-component conceptualization of organizational commitment.Human Resource Management Review 1(1):61-89.

[6]Amauche, E., Bahyah, A.H. \&Zainudin, A. (2019).The influence of quality of worklife (QWL) and organizational commitment on job performance among academics in the Malaysian public universities. International Journal of Humanities and Social Science Research. 5 (5) 71 76

[7]Ariyabuddhiphongs, V., \& Kahn, S. I. (2017). Transformational Leadership And Turnover Intention: The Mediating Effects Of Trust And Job Performance On Café Employees In Thailand, Journal Of Human Resources In Hospitality \& Tourism, 16(2), 215-233,

[8]Arora, R., \&Rangnekar, S. (2015). The joint effects of personality and supervisory career mentoring in predicting occupational commitment. Career Development International, 20(1), 63-80. doi:10.1108/CDI-12-2014-0156 [9]Atiomo, A.C. (2000).Practical Human Resources Management. Lagos, Nigeria

[10]Ayfer, K. \&Manar, A. (2019). The relationship between the quality of work and organizational commitment of prison nurses. The Journal of Nursing Research, 27(3), e25. doi:10.1097/jnr.0000000000000286

[11]Azeem, M.S. \&Akhtar, N. (2014). Job satisfaction and organisational commitment among public sector employees in Saudi Arabia .International Journal of Business and Social Sciences, 5(7): 127-133.

[12]Babalola, M. T., Stouten, J., \&Euwema, M. (2016). Frequent change and turnover intention: The moderating role of ethical leadership. Journal of Business Ethics, 134(2), 311-322. doi:10.1007/s10551-014-2433-z 


\section{Mediating Effect of Job Embeddednesss on the Relationship between Quality of Work Life and Organizational Commitment in Taraba State Higher Institutions of Learning. A Conceptual Paper}

[13]Cem, B. \&Gundogmus, F. (2018).The Effect of Work-Life Balance on Organizational Commitment of Accountants, Management, University of Primorska, Faculty of Management Koper, vol. 13(2), pages 137-159.

[14]Cesario, F., \&Chambel, M. J. (2017). Linking organizational commitment and work engagement to employee performance. Knowledge and Process Management, 24(2), 152-158. doi:10.1002/kpm.1542.

[15]Charlier, S.D., Stewart, G.L., Greco, L.M. \& Reeves, C. J. (2016) Emergent leadership in virtual teams: A multilevel investigation of individual communication and team dispersion antecedents. The Leadership Quarterly 27(5)

[16]Da Silva, L. P., Castro, M. A. R., Dos-Santos, M., \&Neto, P. J. d. L. (2018).Commitment to work and its relationship with organizational culture mediated by satisfaction.RevistaBrasileira De Gestão De Negócios, 20(3), 401-420. doi:10.7819/rbgn.v20i3.3947

[17]Darko-Asumadu, D. A., Sika-Bright, S. \&Osei-Tutu, B. (2018). The Influence Of Work-Life Balance On Employees' Commitment Among Bankers In Accra, Ghana. African Journal Of Social Work, 8(1) 47 -55 [18]Dechawatanapaisal, D. (2018). Examining the relationships between HR practices, organizational job embeddedness, job satisfaction, and quit intention. Asia - Pacific Journal of Business Administration, 10(2), 130-148. doi:10.1108/APJBA-11-2017-0114

[19]Delecta, P (2011). Work-Life Balance.International Journal of Current Research. 3: 186-189.

[20]Delobbe, N \&Vandenberghe, C. (2000). A Four-Dimensional Model Of Organizational Commitment Among Belgian Employees. European Journal Of Psychology Assessment 16(2):125-138.

[21]Dessler, G. (2015) Fundamentals of Human Resource Management. 4th Edition, Global Edition, Pearson International.

[22]Duma, F.S. (2016), Integration of the stock markets from the European union. A convergent or a divergent process?Online Journal Modelling the New Europe, 19 (1) 18-28

[23]Duygu, T. Y. (2019). A Systematic Review of the Correlates and Outcomes of Employee Engagement. IGI Publisher of timely knowledge [24]Eberly, M.B., Bluhm, D.J., Guarana, C., Avolio, B.J. \& Hannah, S.T. (2017), Staying after the storm: how transformational leadership relates to follower turnover intentions in extreme contexts, Journal of Vocational Behaviour, 102 72-85

[25]Eberman, L., Mazerolle, S. M., Eason, C. M. (2019). Formal and informal work-life balance practices of athletic trainers in collegiate and university settings. Journal of Athletic Training, 54(5), 556-561.Edem, M J., Akpan, E. U. \&Pepple, N. M. (2017).Impact of Workplace Environment on Health Workers.Occupational Medical Health Affairs, 5(2), 1-5

[26]Egberi, A. K. (2020). Structural Equation Modeling Of Work-Life Balance, Job embeddednessand Intent To Stay. International Journal Of Business And Management Review. 8 (4) 1-10

[27]Eren, H., \&Hisar, F. (2016).Quality of work life perceived by nurses and their organizational commitment level.International Journal of Human Sciences, 13(1), 1123-1132.

[28]Fako, T.T .,Orlando, E.N., Wilson, D.R., Ntonghanwah, F. \& James, G L. (2018). Factors Associated With Organizational Commitment Of Academic Employees In Botswana. International Journal Of Educational Administration And Policy Studies. 10(6), 56-64

[29]Faloye, D. O. (2014). Organizational Commitment And Turnover Intentions: Evidence From Nigerian Paramilitary Organization. International Journal Of Business \& Economic Development, 2(3), 23-34.

[30]Fontinha, R., Easton, S., Van Laar, D. (2019). Overtime and quality of working life in academics and nonacademics: The role of perceived work-life balance. International Journal of Stress Management, 26(2), 173.

[31]Fapohunda, O. (2019). Strategies For Mitigating Employee Turnover In Thenigerian Financial Services Industry. Walden DessertationsAnd Doctoral Studies Collections

[32]Flippo, E. (1980).Principles of Personnel Management (5thed) Mac Graw Hill, UK.

[33]French, W. (1974).Objectives of Training and Development. The American Management Association Inc., USA.

[34]Glueck, W.F. (1986). Personnel: A Diagonostic Approach. Business Publication Inc., Texas.

[35]Guzeller, C.O. and Celiker, N. (2019), "Examining the relationship between organizational commitment and turnover intention via a meta-analysis", International Journal of Culture, Tourism and Hospitality Research, Vol. $14 \quad$ No. $\quad 1, \quad$ pp. 102-120. https://doi.org/10.1108/IJCTHR-05-2019-0094

[36]Hameed, A., Ramzan, M., Zubair, H. M. K., Ali, G. \&Arslan, M (2014). Impact of Compensation on Employee Performance (Empirical Evidence from Banking Sector of Pakistan). International Journal of Business and Social Science. 5(2);302-309.

[37]Herzberg, F. (1966).Work and the nature of man. Cleveland: World Publishing Company.
[38]Holtom, B.C, Mitchell, T.R \& Lee, T.W. (2006).Increasing human and social capital by applying job embeddedness theory.Organizational Dynamics 35(4):316-331.

[39]Hom, P. W., Tsui, A.S., Wu, J.B., Lee, T.W., Zhang, A.Y., Fu, P.P.\& Li, L. (2009).Explaining employment relationships with social exchange and job embeddedness. Journal of Applied Psychology 94(2):277-297.

[40]Idris, A. (2014). Flexible working as an employee retention strategy in developing countries: Malaysian bank managers speak. Journal of Management Research, 14(2), 71-86.

[41]Igbaekemen, G. O. \&Idowu, O. A. (2014). Impact Of Organizational Commitment On mployees Productivity: A Case Study Of Nigeria Brewery, Plc. International Journal Of Research In Business Management. 2 (9) $107-$ 122

[42]Iliya, A. \&Loko, I.G. (2015). Assessment Of Teacher Motivation Approaches In The Less Developed Countries .Journal Of Education And Practice. $6(22)$

[43]Imran, A. S., Tamas C., Umair, A., Amit, Y. \& Hassan, R. (2020) Multifaceted Role of Job EmbeddednessWithin Organizations: Development of Sustainable Approach to Reducing Turnover Intention. Journal of sage publication DOI: 10.1177/2158244020934876.

[44]Inioluwa C. A., Segun I. P., Anthony, U. A., Aderemi, A. A. \&Oluyemi, O. F. (2019). Research Trends In Nigerian Universities: Analysis Of Number Of Publications In Scopus (2008-2017), International Journal Of Civil Engineering And Technology 10(3), 148-157.

[45]Jeřábek, Z. (2016), Predispositions of an applicant for an employment advantage for getting hired and for the length of an employment, ActaOeconomicaUniversitatisSelye. 5 (1) 73-84.

[46]Jolly, S. (2019). Role Of Quality Of Work Life In Determining Employee Engagement And Organizational Commitment In Telecom Industry. International Journal Of Quality Research 13(2)

[47]Jonathan, P. (2019). Effective Strategies to Increase Employee Commitment and Reduce Employee Turnover.Walden Dissertations and Doctoral Studies Collection. Walden University Scholar Works.

[48]Katsikea, E., Theodosiou, M., \& Morgan, R. E. (2015). Why people quit Explaining employee turnover intentions among export sales managers. $\begin{array}{llll}\text { International } & \text { Business } & \text { Review, } & \text { 24(3), }\end{array}$ doi:10.1016/j.ibusrev.2014.08.009

[49]Kolodziej, A. \&Durnas, K. (2018). The Generation Of Human Resource Management In Transforming Organization Environment. Transformations In Business \& Economics, 17,(1)

[50]Kolomiyets,

$\mathrm{T}$

(2016).https://statswiki.unece.org/display/GFM/A+Safe+Working+Environ ment

[51]Kwahar, N., \&Iyortsuun, A.S. (2018).Determining the Underlying Dimensions of Quality of Work Life (QWL) in the Nigerian Hotel Industry.Entrepreneurial Business and Economics Review, 6(1), 53-70. https://doi.org/10.15678/EBER.2018.060103

[52]Ladislav, M., Barbora, G., Emilia, D. S. \&Zuzana, H. (2019). "Position of Employee Benefits in Remuneration Structure", Transformations in Business \& Economics, 18 (2).156-173. Latham, G. P., Borgogni, L., \&Petitta, L. 2018. Goal setting and performance management in the public sector.Interna-tional Public Management Journal 11(4): 385-403.

[53]Lambert, E., Kelley, T., Hogan, N. (2013).Hanging on too long: The relationship between different forms of organizational commitment and emotional exhaustion burnout among correctional staff.American Journal of Criminal Justice, 38 (1) 51-66

[54]Lee, T.W., Mitchell, T.R., Sablynski, C.J., Burton, J.P, \&Holtom, B.C (2004). The effects of job embeddedness on organizational citizenship, job performance, volitional absences, and voluntary turnover.Academy of Management Journal 47(5):711-722.

[55]Lev, S. \&Koslowsky, M. (2012a).On-the-job embeddedness as a mediator between conscientiousness and school teachers' contextual performance.European Journal of Work and Organizational Psychology 21(1) $57-83$

[56]Lopez,

C.

(2018)

https://familylivingtoday.com/work-life-balance-modern-era/

[57]Lumley, E. J. (2009). Exploring the relationship between career anchors, job satisfaction and organisational commitment.Master's dissertation, University of South Africa, Pretoria.

[58]Luthans, F. (2010).Organizational Behavior: An Evidence-Based Approach. USA: McGraw Hill Irwin.

[59]Mallol, C.M., Holtom, B.C.\& Lee, T.W. (2007). Job embeddedness in a culturally diverse environment.Journal of Business Psychology 22(1):35-44. [60]Medhi, B. (2021). Major Factors Affecting The Quality Of Work Life. https://blog.vantagecircle.com/quality-of-work-life-qwl/

[61]Mehwish, J., Abeera, A., Aideed, B. \& Tania, H. (2019). Human resource practices and organizational commitment: The mediating role of job satisfaction in emerging economy, Cogent Business \& Management, 6 (1) 1608668 , DOI $10.1080 / 23311975.2019 .1608668$ 
[62]Mihokova, L., Andrejovska, A., \&Martinkova, S. (2016), Categorization of corporate taxation in the European Union countries using cluster analysis: A comparative study, Economic Annals-XXI, 160 (7) 4-8.

[63]Mitchell, T.R., Holtom, B.C., Lee, T.W., Sablynski, C. J. \&Erez, M. (2001). Why people stay: Using job embeddedness to predict voluntary turnover. Academy of Management Journal 44(6):1102-1121.

[64]Mohammd, A., Rand, A. \&Ra'ed, M. (2019).Factors that affect Employees Job Satisfaction and Performance to Increase Customers' Satisfactions.Journal of Human Resources Management Research, DOI: $10.5171 / 2019.354277$

[65]Mowday, R. T., Porter, L. W., \& Steers, R. (1982).Employee-organization linkages: The psychology of commitment, absenteeism, and turnover. New York, NY: Academic Press.

[66]Muhammad, R., Muhammad, Q. A., Hafiz, M. A., Faisal, I. \& Atta, H (2014). Determinants Of Employees Intention To Leave: A Study From Pakistan. International Journal Of Human Resource Studies ISSN 2162-3058 2014, 4 (3)

[67]Naithani, P. (2010). Overview of work-life balance discourse and its relevance in the current economic scenario. Asian Social Science journal, 6(6), 148-155.doi:10.5539

[68]Nave, J. H. (1968).Construction personnel management.Journal of Construction Division, 94, 95-105.

[69]Ng, T.W. \& Feldman, D.C. (2007), Organisationalembeddedness and occupational embeddedness across career stages, Journal of Vocational Behavior, 70 (2) 336-351.

[70]Ngatuni, P. \&Matoka, C. (2020).Relationshipsamong Job Satisfaction, OrganizationalaffectivecommitmentAnd Turnover Intentions Of University Academicians In Tanzania. The Pan-African Journal Of Business Management, 4 (1). 47-68

[71]Nia K. R. \&Maleki, M. (2013), A Study On The Relationship Between Quality Of Work Life And Organizational Commitment Of Faculty Members At Islamic Azad University, International Journal Of Research In Organizational Behavior And Human Resource Management, 1 (4) [72]Nicholas, R. (2020). 8 Ways to Increase Quality of Work Life. https://30hourjobs.com/blog/quality-of-work-life/

[73]Normala, D. (2010). Investigating The Relationship Between Quality Of Work Life And Organizational Commitment Amongst Employees In Malaysian Firms. International Journal Of Business And Management, 5(10), 75-82.

[74]Normala, D., Yazlinda, Y. \&Siti, M. G. (2015). Quality Of Work Life And Organizational Commitment: Empirical Investigation Among Academic In Public Institution Of Higher Learning. International Journal Of Applied Business And Economic Research 13 (7) 6129-6146

[75]Noushin, K. S. (2013) Studying The Relationship Between Quality Of Work Life And Organizational Commitment, Research Journal Of Recent Sciences, 3(2)

[76]Olexová, C., Mesároš, P., Bašistová, A. (2011), “Priority riadenial'udskýchzdrojov v znalostnejspoločnosti”, Trendy v podnikání, 1(1) 11-19, [Human resource management priorities in the knowledge society, in Slovak].

[77]Oludayo, O.A., Falola, H.O., Ahaka, O. \&Fatogun, D. (2018).Work-life balance initiative as a predictorof employees' behavioural outcomes. Academic of Strategic Management Journal, 17(1), 1-17

[78]Osibanjo, A. O., Waribo, Y. J,Akintayo, D. I,Adeniji, A. A. and Fadeyi, O. I, (2019).The Effect of Quality of Work Life on Employees' Commitment Across Nigerian Tech Start-Ups,InternationalJournal of Mechanical Engineering and Technology,10(3).41-59.

[79]Rabindra. K., Pradhan, L., Kesari, J.\&Itishree, G.K. (2016).Effect of Work-Life Balance on Organizational Citizenship Behaviour: Role of Organizational Commitment. Global Business Review 17(3)

[80]Radha,Y. \&Ashu K. (2014). Literature Review On Quality Of Work Life And Their Dimensions, IOSR Journal Of Humanities And Social Science. 19 (9).

[81]Robertson, T. (2020) The Effects of Autonomy on Job Satisfaction. Work Chron.com, http://work.chron.com/effects-autonomy-job-satisfaction-14677.html. Accessed 09 March 2020.

[82]Rusdiyanto, J. (2020). Gaining Leader-Employee Commitment: Linking to Organization Performance in Women Cooperative.Advances in Economics, Business and Management Research, 115 (1) 266-268

[83]Qureshi, M.A., Waseem, N., Qureshi,J. A. \&Afshan, S. (2011). Impact of Organizational Commitment on Readiness for Change:A Case of Higher Learning Institutions of Karachi

[84]Selda T.A. (2014). Quality Of Work-Life On Organizational Commitment: A Comparative Study On Academicians Working For State And Foundation Universities In Turkey. International Journal Of Social Sciences. 3(4) 124
[85]Singh, A., \& Gupta, B. (2015). Job Involvement, Organizational Commitment, Professional Commitment, And Team Commitment. Benchmarking: An International Journal, 22(6), 1192-1211. Doi:10.1108/BIJ-01-2014-0007

[86]Spector, P.E. (2008). Industrial and organisational psychology behaviour.5th edition. New Jersey: Wiley.

[87]Steel, R. P., Griffeth, R. W., \&Hom, P. W. (2002).Practical retention policy for the practical manager.The Academy of Management Executive, 16(2), 149-162.

[88]Steers, R.M. (1977) Antecedents and Outcomes of Organisational Commitment. Administrative Science Quarterly, 22, 46-56.

http://dx.doi.org/10.2307/2391745

[89]Stefanus, R. \&Zuriana, Z. (2019). Work-life balance as a predictor oforganizational commitment: a multidimensional approach. Diponegoro International Journal of Business 2 (1) 18-22

[90]Stones, T. H. (1982) Understanding Personnel Management. The Dryden Press, New York

[91]Subhasish, C. \&Dipali C. (2015).SsatisfactionAnd Its Relation With Job Security Of Paramedical Staff -With Reference To Various Private Hospitals. International Journal Of Social Science \& Interdisciplinary Research. 4 (5)

[92]Sylwia, S. (2016). The role of remuneration in building employee engagement EISSN 2392-2192

[93]Tigin, L. \&Tjutju.Y. (2019).The Influence of Work Life Balance on the Organizational Commitment of Female Employees.Advances in Economics, Business and Management Research, volume 65 (1)

[94]Tom, S. \& Harris, R. (2017).Harmonising Training and Development across an Industry:

[95]Treuren, G.J. (2017), Employee embeddedness as a moderator of the relationship between work and family conflict and leaving intention, International Journal of Human Resource Management, pp. 1-21.

[96]Upasna, J.S. (2014).Influence of Work Life Balance on Organisational Commitment: A Comparative Study of Women Employees Working in Public and Private Sector Banks, European Journal of Business and Management 6 (34) 215

[97]Weakley,

(2020)

https://workplacediversity.com/news/The-Importance-of-Health-and-Safety -in-the-Workplace-

[98]Yadav, R. ,Khanna, A. , Panday, P. and Dasmohapatra, S. (2019) An Analytical Study of Quality of Work Life \&Organisational Commitment and Their Relation with Revenue per Employee of Major IT Companies in India. Journal of Human Resource and Sustainability Studies, 7, 284-301. doi: 10.4236/jhrss.2019.72018.

[99]Yousaf, S., Latif, M., Aslam, S., Saddiqui, A. (2014), "Impact of Financial and non Financial Rewards on Employee Motivation. Middle-East", Journal of Scientific Research, Vol. 21, No 10, pp.1776-1786, doi.org/10.5829/idosi.mejsr.2014.21.10.21756.

[100]Yousef, D.A. (2017) Organizational Commitment, Job Satisfaction and Attitudes toward Organizational Change: A Study in the Local Government, International Journal of Public Administration, 40:1, 77-88, DOI: 10.1080/01900692.2015.1072217

[101]Ziba, B. \& Mohammad, G. (2017).The Study of the Quality of Working Life with Organizational Commitment and Job Satisfaction among the Employees Using Correlation Analysis.European Online Journal of Natural and Social Sciences 6 (1) 100-110

[102]https://www.google.com/search?client=firefox-b-d\&q=world+human+ capital+index

[103]https://www.nbs.gov.sc/downloads/other-publications/annual-publicati ons

[104]https://www.timeshighereducation.com/world-university-rankings/202 0/world-ranking\#!/page/0/length/25/sort_by/rank/sort_order/asc/cols/stats [105]http://www.ceic2018.org

[106]http://conferences.academicjournals.org/cat/social-sciences/society-for -human-resource-management-global-mobility-and-immigration-symposiu $\mathrm{m}$

[107]https://www.researchgate.net/publication/315748019

[108]https://www.businessnewsdaily.com/5244-improve-work-life-balancetoday.html

Leah Musa, a Lecturer with the Department of Business Administration, Faculty of Humanities, Management and Social Sciences, Federal University Wukari, TarabaState.Education Background: B.Tech Management Abubakar Tafawa Balewa University, Bauchi.

M BA Management Abubakar Tafawa Balewa University, Bauchi.

M.Sc Management.Bayero University, Kano.

Ph.D management (in view) Bayero University, Kano. 